\title{
The model of the Nociceptive Withdrawal Reflex in horses
}

\author{
Claudia Spadavecchia', Helene Rohrbach' ${ }^{7}$, Olivier Levionnois ${ }^{7}$ and Massimo Leandri ${ }^{2}$ \\ 1 Section of Veterinary Anaesthesiology and Pain Therapy, Department of Clinical Veterinary Medicine, Vetsuisse Faculty, University of Bern, Switzerland \\ 2 Interuniversity Centre for Pain Neurophysiology and Department of Neurology, University of Genova, Italy
}

\begin{abstract}
Summary: In equine pain research, the Nociceptive Withdrawal Reflex (NWR) model has been proposed as an alternative to classical thermal, mechanical and electrical models to investigate the physiology of nociception. This model does not only allow a more reliable definition of the nociceptive threshold through neurophysiological characterization of the elicited response, but also consents plotting a stimulus-response curve as well as the evaluation of temporal summation mechanisms. Aim of this report is to summarize the experience and results obtained using the NWR model in horses over the last 15 years, firstly with the purpose of describing its physiological characteristics and secondly with the aim of evaluating its pharmacological modulation through analgesic and anaesthetic compounds. The NWR can be elicited in horses through electrical transcutaneous stimulation of a peripheral sensory nerve and is recorded through electromyographic electrodes from the muscles involved in the withdrawal reaction. As the non-nociceptive fibres have lower threshold to electrical stimuli than the nociceptive one, it is impossible to differentiate between the two groups on the stimulus side. So, the only guidance to assess the quality of the stimulus and the recruitment of nociceptive afferents should rely on the characteristics of the electromyographic response, most of all on the timing of its various components. A reflex response can be considered to be a true NWR only if it appears within a time epoch compatible with the conduction velocity of the A fibers. Furthermore a clearly recognizable EMG burst in the epoch of interest has to be accompanied by a consistent aversive behavioural reaction, thus allowing the definition of a reliable NWR threshold. Responses to stimulation intensities below and above thresholds can be quantified to draw a stimulus response curve. Furthermore, through repeated stimulation at subthreshold intensities, it is possible to elicit the phenomenon of temporal summation, considered to be the early phase of the wind up phenomenon and of relevant interest to study central integrative mechanisms of pain processing. Alpha-2 agonists, opioids, systemic lidocaine, ketamine and inhalation anaesthetics have been investigated using the NWR model in horses. Drug-specific modulation of NWR threshold, stimulus-response curves and temporal summation are summarized for each tested compound.
\end{abstract}

Keywords: Nociceptive Withdrawal Reflex, horse, pain, anaesthesy, equine, welfare

Citation: Spadavecchia C., Rohrbach H., Levionnois O, Leandri M. (2016) The model of the Nociceptive Withdrawal Reflex in horses. Pferdeheilkunde 32, 416-427

Correspondence: Prof. Claudia Spadavecchia, Section of Veterinary Anesthesiology and Pain Therapy, Department of Clinical Veterinary Medicine, Vetsuisse Faculty, University of Bern, 3012 Bern, Switzerland; e-mail: claudia.spadavecchia@vetsuisse.unibe.ch

\section{Introduction}

The challenge of effectively treating equine pain has accompanied the long history of human-horse relationship through the centuries. Equine athletic performance is strictly linked to a thorough wellbeing: each form of evident clinical pain, acute or chronic, continuous or intermittent, lowers the potential and hence the commercial value of a horse. Orthopaedic trauma, infected synovial structures, myositis and laminitis are typical examples of musculoskeletal conditions that can provoke severe pain in horses. Abdominal colics, accompanied by characteristic behaviours, are distinctive symptoms of visceral pain that can reach dramatic, violent intensity. Efficacious and safe pain-relieving strategies are needed to control spontaneously occurring as well as perioperative pain in horses.

The International Association for the Study of Pain (IASP) states that pain is "an unpleasant sensory and emotional experience associated with actual or potential tissue damage, or described in terms of such damage" (Merskey 1991). In the absence of verbal expression and inability to communicate the subjective feeling of pain perception, the affective, emotional components of equine pain can be inferred if changes in facial expression, appetite, posture or interactive behaviour are noticed. Several behavioural based pain scoring methods have been developed and validated in the attempt to quantify the complex subjective experience of pain and to help targeting pain-relieving treatments in horses (de Grauw and van
Loon 2016). While in clinical settings such methods are very useful, in the pharmacological context models of acute nociception are generally applied to provide first evidence of the antinociceptive activity of a specific compound. Nociception is defined by the IASP as "the neural process of encoding noxious stimuli, and does not necessarily imply pain sensation. Consequences of encoding may be autonomic, like elevated blood pressure, or behavioural, like a withdrawal reflex or a more complex nocifensive behaviour".

In experimental settings involving horses, acute nociception was classically elicited by thermal, mechanical or electrical stimuli, applied continuously to the skin until a behavioural reaction became apparent (Kalpravidh et al. 1984b, Kamerling et al. 1985b, Jochle and Hamm 1986, Chambers et al. 1990). The observation of an aversive behavioural reaction as the end point of each stimulation is a common feature of classical acute nociceptive models, still in use nowadays (Love et al. 2011 ). Pharmacological analgesia is typically defined as the ability of the test drug to increase the tolerance to a stimulus, delaying or totally deleting the onset of the nocifensive reaction. Unfortunately these models do not allow distinguishing between reactions to noxious or non-noxious stimulus intensities, as the response is non-specific. The fact that some commonly used analgesic drugs like alpha-2 agonists may eliminate escape behaviours by provoking sedation and other drugs like opioids may increase the locomotor activity as a result of central nervous system excitation (Kamerling et al. 
1985a), has raised criticism about the validity of the results obtained with these experimental models in horses. Furthermore, all these models merely allow the definition of a single threshold value for each experimental condition, typically measured as the time necessary to obtain a behavioural reaction after stimulation onset. As an alternative, the Nociceptive Withdrawal Reflex (NWR) model has been proposed to investigate the physiology of nociception and to evaluate its modulation by analgesic and anaesthetic drugs in horses (Spadavecchia et al. 2002, Spadavecchia et al. 2003, Spadavecchia et al. 2007, Rohrbach et al. 2009). This model not only allows a more reliable definition of the nociceptive threshold through neurophysiological characterization of the elicited response (Spadavecchia et al. 2002), but also allows to plot a stimulus-response curve together with the assessment of temporal summation mechanisms (Spadavecchia et al. 2004). Aim of this review is to summarize the experience and results obtained using the NWR model in horses over the last 15 years.

\section{The physiology of the Nociceptive Withdrawal Reflex}

The nociceptive withdrawal reflex (NWR) is a polysynaptic spinal reflex responsible for the nocifensive reaction to protect the body's integrity against a damaging stimulus. Described first in cats by Sherrington at the beginning of the last century (Sherrington 1910), the NWR has been extensively applied for the study of experimental nociception in laboratory animals (Schovenborg and Kalliomaki 1990, Leandri et al. 2011 ) and human beings (Schovenborg and Kalliomaki 1990, Curatolo et al. 1995, Andersen et al. 2001, Banic et al. 2004, Neziri et al. 2010, Leandri et al. 2011 ).

The NWR is characterized by 3 particular features: 1) it has a wide receptive field, from skin and muscle nociceptors; 2) it irradiates to muscles of the entire limb and into other limbs, evoking a crossed extension reflex in the contralateral limb and flexion and extension movements in the other limbs, with a possible posture-stabilizing function 3) it may suppress other reflexes. It results from peripheral stimulation able to activate group III and IV muscle afferent fibers and nociceptive (A $\delta$, thinly myelinated and $C$, unmyelinated) cutaneous afferent fibers, which belong to the Flexor Reflex Afferents system and converge onto the common reflex pathways (Lundberg 1979). Nociceptive information tends to predominate over other sensorial inputs. A nociceptive input initiates the flexion reflex, which prevails on the on-going movements, and promptly modifies the motor program to protect the body against the potential tissue damage (Behrends et al. 1983). Primary afferent input, descending inhibition and the intrinsic excitability of neurons involved in the reflex pathway play a role in the generation of the NWR.

Experimentally it is possible to elicit the reflex by transcutaneous electrical stimulation of a sensory peripheral nerve and to record the electromyographic response from the muscles involved in the withdrawal reaction. The nociceptive component of the reflex appears on the EMG in a specific time window following stimulation, depending mainly on activation of A $\delta$ fibers. Thus the nociceptive reflex can be visualized, quantified and correlated to the stimulus intensity (Chan and Dallaire 1989).
In human volunteers the NWR has been extensively used as a reliable tool to define and quantify spinal nociceptive processing and as a supplement to psychophysical methods for pain assessment (Andersen et al. 1999). The strong correlation between evoked NWR and perceived subjective pain sensation justifies the application of the NWR in human pain research. From early human experiments it was reported that the repetition of a noxious stimulus leads to selective increase in the nociceptive reflex amplitude, prolongation of the reflex EMG discharge and progressive intensification of the perceived pain. This facilitation of the nociceptive reflex response, originating from the temporal summation of sensory inputs, has been proposed as a tool to investigate and quantify in a non-invasive way the physiology of central integrative and sensitization processes in humans (Arendt-Nielsen et al. 1994).

\section{Eliciting and recording the NWR in horses}

The NWR is typically measured in horses restrained in stocks in standing position. A standardized posture, with symmetric limb loading, is crucial during measurements as the NWR is modulated in a load dependent manner (Rossi and Decchi 1994).

Transcutaneous electrical stimulation of a limb peripheral nerve is usually applied to evoke the NWR (Willer 1977, Curatolo et al. 1995). Electrical stimulation is easy to use and adequate to elicit stable and reproducible reflexes, bypassing the influence of peripheral transduction mechanisms. Stimuli are delivered via self-adhesive electrodes, as previously described in human experiments (Andersen et al. 1995). The electrodes are applied to the clipped and degreased skin over the palmar (Spadavecchia et al. 2002) or plantar (Spadavecchia et al. 2003) digital nerves, which are purely sensory nerves in horses. They are fixed on their limbs during the entire experimental session, so that the animals cannot relate any external sign to the upcoming stimulus.

Stimulation is provided by a battery-powered, optoisolated constant current stimulator. A standard stimulus configuration is generally adopted for its high efficacy in eliciting nocifensive responses: each stimulus consists of 5 constant current square-wave pulses, each of $1 \mathrm{~ms}$ duration and delivered at a frequency of $200 \mathrm{~Hz}$ (Andersen et al. 1995, Neziri et al. 2010).

The reflex response to electrical stimulation is recorded by surface electromyography using pairs of bipolar self-adhesive electrodes placed on muscles involved in the reflex withdrawal. For the forelimb, the extensor carpi radialis, the common digital extensor, the ulnaris lateralis and the deltoid have been evaluated, while for the hindlimb only the tibialis cranialis was used so far. The EMG recording is performed from $100 \mathrm{~ms}$ before to $400 \mathrm{~ms}$ after the stimulus onset, resulting in a total recording time of $500 \mathrm{~ms}$ (Spadavecchia et al. 2002). During the entire experimental session, flexible leads and electrodes have to be secured with adhesive bandages to avoid displacements and to prevent disturbances to the horse. Figure 1 shows a horse ready for the experimental session while figure 2 shows typical records from the deltoid muscles elicited by increasing stimulation intensities. 


\section{Quantifying and defining the NWR}

Measures of timing, amplitude or energy of a reflex response to a certain stimulus can be used for its quantification on the EMG record (Andersen 1996). Timing is usually reported as onset latency, the time elapsed from the stimulus onset to the onset of the reflex, recognized on the EMG as a deflection from the baseline. Afferents with different conduction velocities are simultaneously activated by electrical stimuli of sufficient intensity so that, on the basis of their latencies, reflex components of different origin can be recognized and quantified. The first component usually observed is likely to derive from activation of non-nociceptive fast conducting fibers, like A $\beta$ fibers. In humans it has been commonly defined as the RII (Willer 1977). The nociceptive component (NWR, often defined as RIII in humans) is the one deriving from activation of A $\delta$ fibers, with an afferent conduction velocity ranging from 4 to $36 \mathrm{~m} / \mathrm{s}$ (Gasser and Erlanger 1927). For horses, on the basis of experiences collected in several experiments, the epochs $80-250 \mathrm{~ms}$ or $40-200 \mathrm{~ms}$ after stimulation seem the most suitable to recognize the NWR, depending on the specific experimental settings chosen (Spadavecchia et al. 2002, Spadavecchia et al. 2003, Risberg et al. 2014). Later components, possibly deriving from activation of slow conducting nociceptive $C$ fibers, are difficult to recognize as they are contaminated by supraspinal reactions.

The root-mean-square amplitude of the EMG trace over the predefined nociceptive post-stimulation epoch has been used to quantify the reflex size and define the NWR threshold. To be considered an NWR, the reflex component in the epoch of interest has to be at least 3 times the background activity (EMG recorded before stimulus onset) (Spadavecchia et al. 2002, Spadavecchia et al. 2003) or to have a RMS amplitude of at least $30 \mu \mathrm{V}$ (Risberg et al. 2014).

In the studies object of this review, the individual NWR threshold was considered as the minimum current intensity capable to evoke a NWR, accompanied by a consistent behavioural reaction, in at least two successive stimulations of the same intensity (Spadavecchia et al. 2002, Spadavecchia et al. 2003). In the literature, different methods to determine the NWR threshold have been reported. Classically, the threshold is defined as the intensity that evokes a reflex response following $50 \%$ of the stimuli, but percentage of $60-70 \%$ (Willer and Bathien 1977) or 70-80\% (Willer and Bussel 1980) have been chosen by some authors. Alternatively several stimulations of increasing intensities have been applied and the threshold estimated as the average of the lowest intensities evoking a reflex in a predetermined post-stimulation interval (Bouhassira et al. 1994). A threshold definition similar to the one described in horses was introduced by Andersen in human experiments (Andersen 1996) with the aim to reduce the number of stimuli needed and thereby the total duration of the experimental session. Compared to previously described values obtained with the methods of percentages, threshold intensities found with these criteria were possibly higher. If two successive stimuli of the same intensity have to evoke the reflex, it means that nearly $100 \%$ of positive responses have to be obtained before considering the current intensity as threshold intensity. This method for determination of the threshold probably allows higher reproducibility and clearness of responses, fundamental whenever repeated measure- ments are foreseen and pharmacological threshold modulation has to be tested.

For the work with conscious non-medicated horses it appeared important to have experimental sessions as short as possible and reliable thresholds for further studies on pharmacological modulation.

\section{Temporal summation: background and experiences in horses}

Activity dependent changes in excitability of central neurons play a fundamental role in pain hypersensitivity and development of chronic pain (Dubner 1991). In neurophysiological experimental settings, it was observed that repetition of a fixed stimulus at low frequency, able to activate afferent $C$ fibers, results in a progressive build-up in the amplitude of the response, recorded as action potential discharge in dorsal horn neurons (Mendell and Wall 1965): this activity dependent facilitation was defined "windup". Windup is used as a model of spinal neuroplasticity and central sensitization but its neurophysiologic investigation is possible only in experimental conditions in anesthetized or spinalized animals, as invasive procedures are required. In humans, temporal summation of afferent nociceptive inputs has been proposed as a psychophysical and electrophysiological correlate of the early

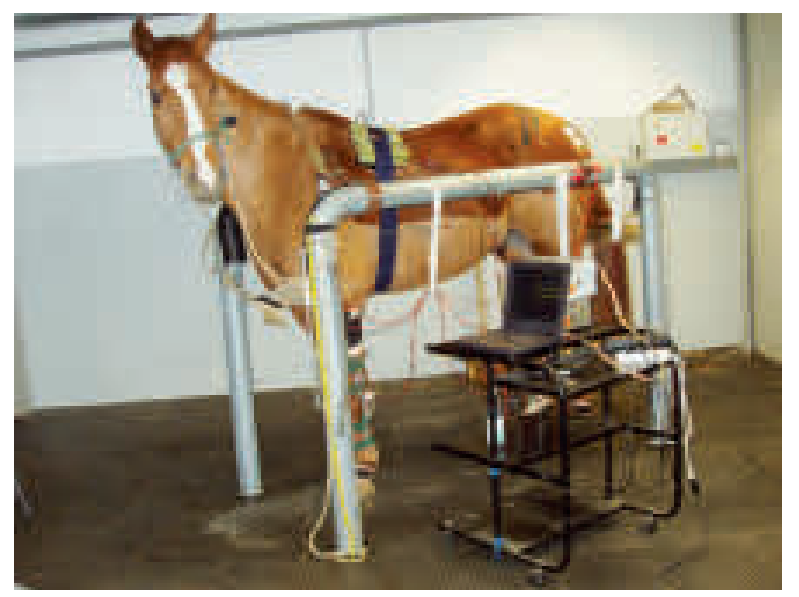

Fig. 1 Horse fully prepared for starting the experiment

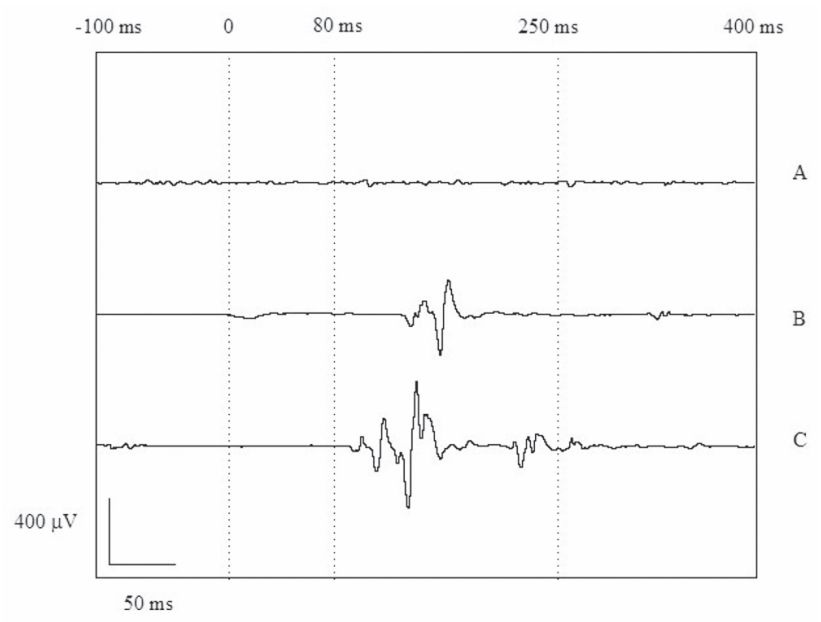

Fig. 2 Records from the deltoid muscle. Stimulations at A) $2 \mathrm{~mA}$, B) $3 \mathrm{~mA}$, and C) $4 \mathrm{~mA}$. 
phase of wind-up (Arendt-Nielsen et al. 1994). Similar to wind-up, temporal summation is strongest when stimulation is applied at C fibers strength. Nevertheless, data obtained in animals (Sivilotti et al. 1993) and humans (Shahani and Young 1971) indicate that it is possible to evoke central summation of both $C$ and $A \delta$ fibers in experimental settings. The mechanism of temporal summation is believed to involve a prolonged discharge of wide dynamic range neurons in the dorsal horn, which receive inputs from both $A \delta$ and $C$ fibers. The change in pain quality, from pure sharp pain to aching pain, reported in humans undergoing repetitive stimulations, suggests that $C$ fibers mediated activity could summate with Ad mediated activity (Andersen et al. 1994). In view of this, the NWR attributed to activation of A fibers, has been proposed as a noninvasive model to study and quantify aspects of central integration in humans: a single non-noxious stimulus, unable to evoke the NWR (i.e., sub-threshold), can integrate causing pain and facilitation of the NWR if given repeatedly (Arendt-Nielsen et al. 2000). The facilitation is accompanied by increasing pain perception for successive stimuli of the same intensity, indicating that a summation of sensory inputs occurs over time. Since its first description (Arendt-Nielsen et al. 1994) this model has been employed extensively to test the efficacy of analgesic drugs and procedures in humans (Curatolo et al. 1995, Curatolo et al. 1997). Inhibition of temporal summation has been indicated as a major goal in pain prevention and treatment. Moreover methods to assess temporal summation have been suggested for sensory assessment in patients with sensory dysfunction in clinical settings (Curatolo et al. 2001, Biurrun Manresa et al. 2011).

The basic physiology of temporal summation has been evaluated in conscious horses using the NWR (Spadavecchia ef al. 2004). The final purpose was to define a method to study the pathophysiology and pharmacological modulation of central integrative processes in horses. After determination of individual NWR thresholds, repeated subthreshold stimulations can be applied to find the threshold intensity able to elicit temporal summation. Temporal summation in humans is both frequency and intensity dependent, so different frequencies and intensities of stimulation were applied to find the best settings capable of evoking summation in horses. In a first methodological study (Spadavecchia et al. 2004), repeated stimuli (each stimulus being a train of 5 pulses as previously

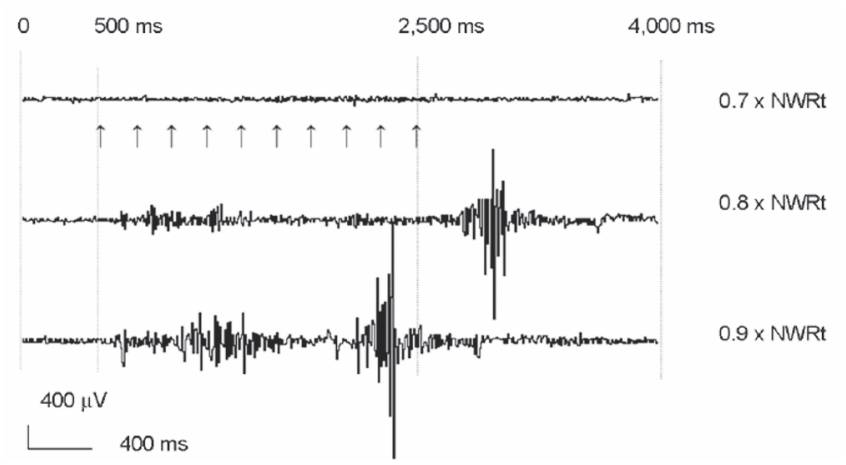

Fig. 3 Repeated stimulations: records from one horse. Stimulation frequency: $5 \mathrm{~Hz}$. Stimulation intensities: $0.7,0.8$ and 0.9 times the individual NWR threshold intensity $(\times N W R+)$; following stimulations at 0.8 and $0.9 \times N W R t$, electromyographic activity is present also after the end of stimulation: the horse lifted the limb many times. described) were applied at the frequencies 2, 5, and $10 \mathrm{~Hz}$ for the forelimb and at the frequency of $5 \mathrm{~Hz}$ for the hind limb. At each frequency, the current intensities of $0.7,0.8$ and 0.9 times the individual NWR threshold were applied (Figure 3).

Expecting a certain similarity with human experimental data, temporal summation was anticipated to occur within this intensity range. The total stimulation time was set at $2 \mathrm{~s}$, as in most human experiments, and the EMG response was recorded for $4 \mathrm{~s}$ : $500 \mathrm{~ms}$ prestimulation, $2000 \mathrm{~ms}$ during stimulation and $1500 \mathrm{~ms}$ poststimulation (Spadavecchia et al. 2004). The experience collected over the last years indicates that the best method to quantify the NWR facilitation consists in the determination of the RMS amplitude of the reflex response within the 40-200 ms window following each stimulus (Risberg et al. 2014). Nevertheless preliminary trials revealed that once the summation effect is initiated, the individual NWR can be recognized only with difficulty because of the gross limb movement mostly accompanied by strong generalized increase in the EMG activity. Problems in detecting the precise onset of the reflex from the contamination of the background EMG activity have been reported in humans too, even if the volunteers were encouraged to relax between stimuli (Arendt-Nielsen et al. 1994). Working with horses it appears impossible to control and avoid a possible voluntary withdrawal response following the unpleasant sensation associated with repeated stimulation. Consequently, having reached the summation threshold, the recorded EMG response most likely contains spinal and supraspinal (possibly cortical) components.

Stimulation intensity was found to affect significantly the response amplitude during the $2 \mathrm{~s}$ of stimulation, while probably the frequency range applied was too narrow to detect differences among frequencies. Increasing the intensity of an electrical stimulus recruits more $A \delta$ afferents through the mechanism of spatial summation. During the post-stimulation window between 2500 and $4000 \mathrm{~ms}$, a certain degree of EMG activity persisted (Figure 3 ). This most probably reflects the voluntary muscle activation following the end of stimulation, as if the horse would still show annoyance and delayed limb lifting (Spadavecchia et al. 2004).

From the results obtained in horses it appears that the experimental model applied to quantitatively assess temporal summation is valid and reliable and can be used as an additional tool to assess efficacy of analgesic drugs in these species (Spadavecchia et al. 2005, Rohrbach et al. 2009).

\section{Behavioural reactions to electrical stimulations}

In human experimental pain research the volunteer is always asked to judge the intensity and quality of the perceived sensation during stimulations (Andersen et al. 1996). Visual analogue scales (VAS), numerical pain rating or pain questionnaires have been used for this purpose (Neziri et al. 2010). In conscious animals, as in infants lacking verbal expression, the quality and intensity of provoked sensations can only be guessed by the investigator (Gracely 1999). In NWR equine studies, observation and scoring of behavioural reactions to electrical stimulations is usually performed to complement neurophysiological data (Spadavecchia et al. 2003) and is 
very useful to consistently define the NWR threshold (Risberg et al. 2014). On the basis of experimental observations, a specific numerical scale was introduced. Each numerical score corresponded to a precise behavioural pattern. Typically, when the first activity burst appears on the EMG record, a sudden whole body reaction occurs (Spadavecchia et al. 2002). The described feeling of pricking pain reported by human volunteers when the sensation starts to become painful could be responsible for such recurrent behaviour. This type of reaction does not consistently imply the presence of a NWR, as it could reflect a sub-threshold stimulus intensity. Some horses lift the limb with delay, following the whole body reaction. Following stimulations of intensities at or above the threshold, a direct quick lifting of the stimulated limb can be observed (Risberg et al. 2014). The scoring system applied in equine studies was adequate to describe the pattern of reactions and to detect changes related to differences in stimulus intensity (Spadavecchia et al. 2003). Different observers were always concordant in attributing a certain score to an observed reaction, confirming that it is easy to recognize stereotypical responses to electrical stimulation in horses (Risberg et al. 2014). When repeated stimulations are applied to evoke temporal summation, more complex behaviours are generally observed (Spadavecchia et al. 2004). A specific movement of the stimulated limb with a recurrent pattern of maintained muscle contraction is the most frequently observed reaction at summation threshold levels, accompanied or not by slight or moderate whole body reactions (Spadavecchia et al. 2004). Human volunteers in similar experimental settings describe distinct sharp pricking pain after the first 2 or 3 pulses followed by more diffuse and aching pain toward the end of the stimulation train (Arendt-Nielsen et al. 1994). The same could happen in horses, some starting a quick voluntary limb flexion immediately after feeling the first prick and some reacting only later with a slower maintained flexion (Spadavecchia et al. 2004).

\section{Pharmacological modulation of the NWR}

Pharmacological modulation of a nociceptive response is considered to occur when a certain drug is able to modify its threshold. Analgesic activity is generally attributed to a drug when a substantial increase in nociceptive thresholds occurs after its administration (Le Bars et al. 2001). The NWR model does not simply allow to precisely recognize an increase in threshold, but it also permits to describe the pharmacologically induced changes in shape of the stimulus-response curve, providing interesting additional information compared to classical nociceptive tests (Treede 2016). Nevertheless, as other nociceptive tests, the NWR depends on a sensory and a motor component. Modulation can occur potentially both at sensory neurons or at motoneuronal level. During drug testing, in order to distinguish antinociceptive activity from depressed motoneuronal excitability, a monosynaptic reflex, like the $\mathrm{H}$ reflex, should be monitored (Shahani 1970, Andersen 1996). Unfortunately no attempts to elicit and record monosynaptic reflexes in non-sedated horses have been reported so far.

In the following paragraphs the experience collected in equine pharmacological studies based on the NWR model is briefly presented per class of drugs or single compounds.

\section{Alpha-2 agonists}

Alpha-2 agonists, widely used in the equine veterinary practice for sedation and analgesia, were the first drugs chosen to test modulation of NWR and temporal summation in horses (Spadavecchia et al. 2005). Several authors reported about their analgesic efficacy under experimental conditions, using both visceral and somatic pain models (Kamerling et al. 1988, Elfenbein et al. 2009, Robertson and Sanchez 2010). For romifidine, a commonly used alpha-2 agonist, controversial results had been published (Hamm et al. 1995, Moens et al. 2003). In order to contribute to the understanding of the antinociceptive activity of this particular drug in horses, the NWR model was applied for the first time in a pharmacological study.

The main finding was that NWR and temporal summation thresholds increased almost threefold after systemic romifidine $(0.08 \mathrm{mg} / \mathrm{kg} \mathrm{IV})$ and that this increase persisted up to 55 min after drug administration, confirming the antinociceptive action of this alpha-2 agonist (Moens et al. 2003). Even if the difference was not statistically significant, it seemed that romifidine depressed the NWR more than the temporal summation threshold. The specific effect on temporal summation can be an important aspect of alpha-2 agonists activity, considering that these drugs have been suggested as a complement for the treatment of human chronic pain unresponsive to conventional therapy (Eisenach et al. 1995).

Another important finding was that the relative reflex amplitude in the epoch 30-80 ms increased after romifidine administration, suggesting a facilitation of reflex components of non-nociceptive origin when repeated stimulations were applied (Spadavecchia et al. 2005). This could represent an electrophysiological correlate of the hypersensitivity to tactile stimuli observed in horses receiving alpha-2 agonists in clinical practice, known for many years and responsible for the sudden reactions even under profound sedation (Alitalo 1986, Freeman and England 2000).

Later, the antinociceptive properties of xylazine, romifidine and detomidine, administered intravenously at sedative equipotent doses, were compared in a prospective, blinded, crossover experimental trial using the NWR model (Rohrbach et al. 2009). While the extent of antinociception was comparable among the three drugs, the duration of the antinociceptive activity was drug specific, being longer for romifidine $(0.08 \mathrm{mg} / \mathrm{kg})$ than for detomidine $(0.02 \mathrm{mg} / \mathrm{kg})$ and xylazine $(1 \mathrm{mg} / \mathrm{kg})$. Interestingly, the same was not true for sedation, which was maximal in respect to magnitude and duration for detomidine (Rohrbach et al. 2009).

Dexmedetomidine, the active enantiomer of the racemic mixture medetomidine, is the most specific alpha- 2 agonist currently available for clinical use. It is often administered as a continuous rate infusion (CRI), either to treat painful conditions or to decrease the amount of inhalation anaesthetics during general anaesthesia (Gozalo-Marcilla et al. 2013, Gozalo-Marcilla et al. 2015). Three escalating CRI doses (2, 4 , and $6 \mu \mathrm{g} / \mathrm{kg} / \mathrm{h}$ ) were investigated to determine which CRI is the minimal necessary to provide consistent antinociception in conscious horses (Risberg et al. 2014). In this study, for the first time, nociceptive tolerance was determined besides noci- 
ceptive threshold. After the NWR threshold was defined, stimulation intensity was further increased stepwise until a maximal vigorous reaction, defined as the strongest acceptable, was elicited. Thus, two clear end points, nociceptive threshold and tolerance, following both single and repeated stimulations, were used for the evaluation of dexmedetomidine antinociceptive properties. Interestingly, all CRls were able to increase temporal summation threshold and nociceptive tolerance, while only 4 and $6 \mu \mathrm{g} / \mathrm{kg} / \mathrm{h}$ consistently increased the NWR threshold. Variable plasma concentrations, sometimes below the detection limit of $0.02 \mathrm{ng} / \mathrm{ml}$, were found at the time of testing when significant antinociception was present. This shows that antinociceptive activity does not necessarily accompany a specific plasma concentration, indicating that a certain pharmacodynamic profile cannot be inferred from pharmacokinetic data alone.

\section{Opioids}

The increasing interest toward efficacious strategies to treat equine pain has recently shown that opioids remain a fundamental class of drugs, despite the undesired side effects that discouraged their use for decades (Clutton 2010, GozaloMarcilla et al. 2015). Among opioids butorphanol, a synthetic agonist-antagonist, is perhaps the most common substance used in horses. It is administered for control of acute visceral pain (Kohn and Muir 1988), for preanaesthetic medication combined with alpha-2 agonists (Schatzmann et al. 2001, Taylor et al. 2016) and to treat postoperative pain (Clutton 2010). Besides clinical reports of efficacy, results from specifically designed experimental trials are needed to provide objective evidence of consistent pain relief in horses. Several experimental methods have been applied to demonstrate the analgesic properties of butorphanol and to define dose-response relationships in horses. While efficacy in the reduction of acute visceral pain has been widely recognized, controversial results from studies based on somatic pain models contributed to increase the uncertainty about the true usefulness of opioids in horses. In order to evoke somatic pain, thermal (Kalpravidh et al. 1984a, Kamerling et al. 1989) or electrical stimulations (Brunson and Majors 1987) have been applied to obtain an aversive response considered as the test end point. Both heat and electrical current produce phasic pain of short duration, that is known to respond less than tonic pain to analgesics (Le Bars et al. 2001). In case of thermal stimulation, thermosensitive fibers are activated before nociceptive fibers, allowing a learning process to occur.

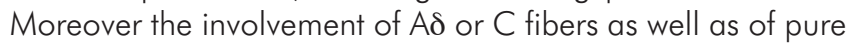
spinal or supraspinal structures depends greatly on the heating slope applied. This parameter was not controlled in the older studies, so that a differentiation of the targets of the drug cannot be performed. In the case of electrical stimulation, a synchronous excitation of fibers of different diameter takes place, but mainly $A \beta$ and $A \delta$ fibers are usually activated during experiments in conscious animals (Le Bars et al. 2001). If the monitored response is purely behavioural, nothing can be concluded about the activated pathways, being simply an indication of a perceived unpleasant sensation that could be evoked by a non-noxious stimulus. As an alternative, the modulation of the NWR and temporal summation has been proposed as objective method to quantify the differential effects of butorphanol on $A \beta$ and $A \delta$ fibers activity and on the drug-related changes in the gain of the nociceptive system (Spadavecchia et al. 2007, Treede 2016).

A single dose of $0.1 \mathrm{mg} \cdot \mathrm{kg}^{-1}$ butorphanol given systemically did not modify the thresholds for NWR and temporal summation, confirming that A $\delta$ fiber evoked activity was not inhibited, as it was demonstrated for other opioids in previous human and laboratory animal experiments (Jurna and Heinz 1979, Cooper et al. 1986, Strimbu-Gozariu et al. 1993, Guirimand et al. 1995). Conversely butorphanol had detectable effects on parameters indicating changes in the gain of the nociceptive system and supraspinal integration, that could justify the clinical evidence of efficacy, even if short lived.

Lately, as an alternative to butorphanol, buprenorphine is gaining interest as an analgesic for horses (Messenger et al. 2011 , Taylor et al. 2014, Love et al. 2015). As no data were available for treatment of foals, the antinociceptive efficacy of buprenorphine in foals was investigated using the NWR model. A dose of $10 \mu \mathrm{g} / \mathrm{kg}$ was administered intramuscularly to foals aged 2 and 11 days. As for butorphanol, the best indicator of buprenorphine antinociception using the NWR model was the significant change in the stimulus-response curve, particularly evident when a single stimulation paradigm was used. Furthermore a significant effect on NWR threshold on 2 day old foals indicated that at least some depressing effects on A $\mathrm{d}$ fibers mediated activity were also present after buprenorphine administration. This effect could not be obtained in 11 day old foals, for reasons still to be investigated.

\section{Systemic lidocaine}

In the last decade systemic lidocaine has become a common component of balanced anaesthesia protocols for horses, as adjunct to inhalants, mainly because it reduces the MAC of inhalant anaesthetics (Dzikiti et al. 2003, Rezende et al. 2011 ). Furthermore lidocaine has been shown to protect tissues against ischemic and reperfusion injuries, it has antiendotoxemic (Peiro et al. 2010) and anti-inflammatory properties (Cook et al. 2009) and it promotes gut motility (Torfs et al. 2009); moreover it is known to suppress development of peripheral hyperalgesia as well as central nociceptive sensitization and allodynia (Doherty and Seddighi 2010). Classically in colic horses systemic lidocaine is used intraoperatively during laparotomies, as a slow bolus $(1.5 \mathrm{mg} / \mathrm{kg})$ followed by CRI $(50 \mu \mathrm{g} / \mathrm{kg} / \mathrm{min})$ or as a CRI alone (Nannarone et al. 2015). Lidocaine CRI is nowadays commonly used following laparotomic surgery, for some days after the intervention, to provide postoperative analgesia (Boesch 2013). It prevents reflux and improves quality of life in the first post-operative days. It can also be used in case neuropathic pain components are evident or suspected (Driessen et al. 2010). In general, care should be taken to recognize its side-effects as muscle weakness and recumbency can occur in case of overdose or reduced metabolism and should not be falsely interpreted as worsening of the condition.

As evidence was lacking about the antinociceptive properties of lidocaine administered alone in horses, 3 escalating doses of intravenous CRls of lidocaine $(20,40$ and $60 \mu \mathrm{g} / \mathrm{kg} / \mathrm{h}) \mathrm{fol}$ lowing a charging bolus were investigated in conscious horses (Risberg et al. 2014). The NWR and temporal summation 
models were applied as reported above for dexmedetomidine. While no evident sedation could be detected during the 3 $\mathrm{CRIs}$, significant and sustained antinociception was found for $40 \mu \mathrm{g} / \mathrm{kg} / \mathrm{h}$ and above. The CRI of $20 \mu \mathrm{g} / \mathrm{kg} / \mathrm{h}$ was merely able to increase the tolerance to repeated stimulations, suggesting that some antihyperalgesic effects might be present even when using very low infusion rates.

\section{Ketamine and S-Ketamine}

Ketamine, a dissociative anaesthetic, is widely used in equine anaesthesia as first choice induction agent. It is a NMDA receptor antagonist useful to prevent wind-up through inhibition of glutamatergic transmission. As distribution and elimination of the drug after bolus administration are quick, it is necessary to administer the drug as a CRI during surgery to prolong its analgesic effects throughout the procedure, as adjunct to inhalation anaesthesia (Gozalo-Marcilla et al. 2014) or during standing surgeries. In the postoperative phase ketamine can be provided as a sub-anaesthetic CRI to control severe pain. Besides providing visceral and somatic analgesia, ketamine decreases the occurrence of opioid-induced hyperalgesia during prolonged opioids treatment (Muir 2010).

Despite clinical evidence of ketamine analgesic effects, experimental evidence of antinociceptive activity in horses was lakking. The compound-specific antinociceptive activity of racemic ketamine and S-ketamine was evaluated when administered at "equipotent" doses as CRls in conscious ponies (Peterbaver et al. 2008). Ponies were administered either $0.6 \mathrm{mg} / \mathrm{kg}$ racemic ketamine (group RS) or $0.3 \mathrm{mg} / \mathrm{kg} \mathrm{S}$-ketamine (group S) followed by $20 \mu \mathrm{g} / \mathrm{kg} / \mathrm{h}$ racemic ketamine (group RS) or $10 \mu \mathrm{g} / \mathrm{kg} / \mathrm{h} \mathrm{S}$-ketamine (group S) for 1 hour. Firstly it was observed that ketamine bolus followed by CRI could be well tolerated by standing ponies that showed only moderate behavioural disturbances, like slight ataxia and increased weight shifting shortly after the bolus. Secondly it was found that while racemic ketamine was able to depress the NWR both at threshold and supra-threshold stimulation intensities, S-ketamine was not, indicating that the expected equipotency of the chosen doses did not include antinociception. In a following study the efficacy of ketamine target controlled infusion in modulating the NWR and temporal summation was investigated under isoflurane anaesthesia (Levionnois et al. 2010). Stimulus-response curves following both single and repeated electrical stimulations were flattened during ketamine infusion targeted at $2 \mu \mathrm{g} / \mathrm{ml}$ and significant NWR and temporal summation threshold changes were found. Partial effects on both thresholds and stimulus-response curves were still observed 70 min following CRI end, showing that a certain antinociceptive and antihyperalgesic activity persists beyond cessation of ketamine administration. The results of these studies (Peterbaver et al. 2008, Levionnois et al. 2010) support the use of low-dose ketamine CRI to provide antinociception in horses.

\section{Inhalation anaesthetics}

The species-specific immobilizing potency of inhaled anaesthetics is usually assessed determining the minimum alveolar concentration (MAC), the ED50 anaesthetic concentration needed to block gross and purposeful movements evoked by a supramaximal stimulus (Eger et al. 1965, Quasha et al. 1980). In the experimental assessment of MAC, which is an "all or none" measure of motor output, the occurrence of reflex movements of single body parts in response to stimulation has traditionally been neglected. Recent research on mechanisms and sites of action of volatile agents has shown that spinal cord effects, more than brain, are responsible for immobility (Antognini et al. 1998, Antognini and Carstens 1999, Sonner et al. 2003). Thus the interest towards graded anaesthetic suppression of simple spinal nociceptive reflexes at anaesthetic concentrations around MAC, as a possible quantitative measure of spinal action, has notably grown. First evidence of correlation between peri-MAC anaesthetic concentrations and nociceptive reflex suppression has been provided for laboratory animals, confirming that an objective quantification of efficacy, besides MAC, is possible (Jinks et al. 2003). Nevertheless some years ago, it was shown in humans that concentrations of isoflurane well below MAC are sufficient to completely suppress nociceptive withdrawal reflexes (Petersen-Felix et al. 1996), so that a peri-MAC quantification of anaesthetic effects could not be performed. This apparent profound discrepancy between human and animal behaviour could suggest important interspecific differences in the mechanisms of anaesthetic action or simply could be due to the different experimental settings applied.

As the NWR model described in horses is analogue to the one applied in the human experiments, it appeared worthy to investigate the effects of isoflurane concentrations around MAC in equines (Spadavecchia et al. 2006, Spadavecchia et al. 2010). The aims were first to provide further animal data to be compared with results obtained in humans, second to see if the NWR can be used as an additional tool to quantify anaesthetic immobilizing potency besides MAC in this species. Ponies instead of horses were used as their reduced size greatly simplified the difficult procedure of mask anaesthetic induction. The isoflurane studies, using both single (Spadavecchia et al. 2006) and repeated stimulation paradigm (Spadavecchia et al. 2010), demonstrated that subtle changes in sensory-motor processing could be detected by NWR assessment. Slight changes in isoflurane concentrations produced parallel changes in the NWR and temporal summation thresholds, and complete suppression of NWR occurred at concentrations able to prevent the occurrence of gross purposeful movements too. These results are in agreement with the ones obtained in laboratory animal experiments, and warrant further investigation on differences between animals and humans. Moreover these studies (Spadavecchia et al. 2006, Spadavecchia et al. 2010) show that it is possible to use measures other than MAC to quantify the immobilizing potency of inhaled anaesthetics in equine. In future, this will allow to compare agent-specific inhibitory potency at equivalent peri-MAC concentrations and to study the effects of anaesthetic combinations.

\section{Conclusions and outlook}

Over the last 15 years, the physiological characteristics of the NWR and temporal summation in horses have been described and quite extensive evidence of their pharmacological modulation has been provided. In this review, we reported the potentialities and limitations of these models of acute pain, 
and analysed the different experimental conditions. It is worth to remark that, besides further studies involving efficacy of new antalgic compounds or strategies of major clinical relevance in equine medicine, the NWR could be used as a complementary quantitative diagnostic tool to assess clinical conditions of sensory dysfunction in horses. Indeed, in the last few years human pain research has gone in such direction, by proposing the NWR as a method to investigate spinal nociceptive hypersensitivity in chronic pain syndromes.

\section{References}

Alitalo I. (1986) Clinical experiences with Domosedan in horses and cattle. A review. Acta Vet. Scand. Suppl. 82, 193-196

Andersen O. K. (1996) Physiological and pharmacological modulation of the human nociceptive withdrawal reflex. PhD Thesis, Center for Sensory-Motor Interaction, Aalborg University, Aalborg, Denmark

Andersen O. K., Felsby S., Nicolaisen L., Bierring P., Jensen T. S., Arendt-Nielsen L. (1996) The effect of Ketamine on stimulation of primary and secondary hyperalgesic areas induced by capsaicin-a double-blind, placebo-controlled, human experimental study. Pain 66, 51-62

Andersen O. K., Jensen L. M., Brennum J., Arendt-Nielsen L. (1994) Evidence for central summation of $C$ and $A$ delta nociceptive activity in man. Pain 59, 273-280

Andersen O. K., Jensen L. M., Brennum J., Arendt-Nielsen L. (1995) Modulation of the human nociceptive reflex by cyclic movements. Eur. J. Appl. Physiol. Occup. Physiol. 70, 311-321

Andersen O. K., Sonnenborg F. A., Arendt-Nielsen L. (1999) Modular organization of human leg withdrawal reflexes elicited by electrical stimulation of the foot sole. Muscle Nerve 22, 1520-1530

Andersen O. K., Sonnenborg F. A., Arendt-Nielsen L. (2001) Reflex receptive fields for human withdrawal reflexes elicited by nonpainful and painful electrical stimulation of the foot sole. Clin. Neurophysiol. 112, 641-649

Antognini J. F., Carstens E. (1999) Increasing isoflurane from 0.9 to 1.1 minimum alveolar concentration minimally affects dorsal horn cell responses to noxious stimulation. Anesthesiology 90, 208-214

Antognini J. F., Carstens E., Tabo E., Buzin V. (1998) Effect of differential delivery of isoflurane to head and torso on lumbar dorsal horn activity. Anesthesiology 88, 1055-1061

Arendt-Nielsen L., Brennum J., Sindrup S., Bak P. (1994) Electrophysiological and psychophysical quantification of temporal summation in the human nociceptive system. Eur. J. Appl. Physiol. Occup. Physiol. 68, 266-273

Arendt-Nielsen L., Sonnenborg F. A., Andersen O. K. (2000) Facilitation of the withdrawal reflex by repeated transcutaneous electrical stimulation: an experimental study on central integration in humans. Eur. J. Appl. Physiol. 81, 165-173

Banic B., Petersen-Felix S., Andersen O. K., Radanov B. P., Villiger P. M., Arendt-Nielsen L., Curatolo M. (2004) Evidence for spinal cord hypersensitivity in chronic pain after whiplash injury and in fibromyalgia. Pain 107, 7-15

Behrends T., Schomburg E. D., Steffens H. (1983) Facilitatory interaction between cutaneous afferents from low threshold mechanoreceptors and nociceptors in segmental reflex pathways to alphamotoneurons. Brain Res. 260, 131-134

Biurrun Manresa J. A., Neziri A. Y., Curatolo M., Arendt-Nielsen L., Andersen O. K. (2011) Test-retest reliability of the nociceptive withdrawal reflex and electrical pain thresholds after single and repeated stimulation in patients with chronic low back pain. Eur. J. Appl. Physiol. 111, 83-92

Boesch J. M. (2013) Anesthesia for the horse with colic. Vet. Clin. North Am. Equine Pract. 29, 193-214

Brunson D. B., Majors L. J. (1987) Comparative analgesia of xylazine, xylazine/morphine, xylazine/butorphanol, and xylazine/nalbuphine in the horse, using dental dolorimetry. Am. J. Vet. Res. 48, 1087-1091
Chambers J. P., Livingston A., Waterman A. E. (1990) A device for testing nociceptive thresholds in horses. J. Ass. Vet. Anaesth. 17, $42-44$

Chan C. W., Dallaire M. (1989) Subjective pain sensation is linearly correlated with the flexion reflex in man. Brain Res. 479, 145-150

Clutton R. E. (2010) Opioid analgesia in horses. The Veterinary clinics of North America. Equine Pract. 26, 493-514

Cook V. L., Jones Shults J., McDowell M. R., Campbell N. B., Davis J. L., Marshall J. F., Blikslager A. T. (2009) Anti-inflammatory effects of intravenously administered lidocaine hydrochloride on ischemiainjured jejunum in horses. Am. J. Vet. Res. 70, 1259-1268

Cooper B. Y., Vierck C. J., Jr., Yeomans D. C. (1986) Selective reduction of second pain sensations by systemic morphine in humans. Pain 24, 93-116

Curatolo M., Petersen-Felix S., Arendt-Nielsen L., Fischer M., Zbinden A. M. (1995) Temporal summation during extradural anaesthesia. Br. J. Anaesth. 75, 634-635

Curatolo M., Petersen-Felix S., Arendt-Nielsen L., Giani C., Zbinden A. M., Radanov B. P. (2001) Central hypersensitivity in chronic pain after whiplash injury. Clin. J. Pain 17, 306-315

Curatolo M., Petersen-Felix S., Arendt-Nielsen L., Zbinden A. M. (1997) Spinal anaesthesia inhibits central temporal summation. Br. J. Anaesth. 78, 88-89

de Grauw J. C., van Loon J. P. (2016) Systematic pain assessment in horses. Vet. J. 209, 14-22

Doherty T. J., Seddighi M. R. (2010) Local anesthetics as pain therapy in horses. The Veterinary clinics of North America. Equine pract. 26, 533-549

Driessen B., Bavquier S. H., Zarucco L. (2010) Neuropathic pain management in chronic laminitis. The Veterinary clinics of North America. Equine pract. 26, 315-337

Dubner R. (1991) Pain and hyperalgesia following tissue injury: new mechanisms and new treatments. Pain 44, 213-214

Dzikiti T. B., Hellebrekers L. J., van Diik P. (2003) Effects of intravenous lidocaine on isoflurane concentration, physiological parameters, metabolic parameters and stress-related hormones in horses undergoing surgery. J. Vet. Med. A Physiol. Pathol. Clin. Med. 50, 190-195

Eger E. I., 2nd, Saidman L. J., Brandstater B. (1965) Minimum alveolar anesthetic concentration: a standard of anesthetic potency. Anesthesiology 26, 756-763

Eisenach J. C., DuPen S., Dubois M., Miguel R., Allin D. (1995) Epidural clonidine analgesia for intractable cancer pain. The Epidural Clonidine Study Group. Pain 61, 391-399

Elfenbein J. R., Sanchez L. C., Robertson S. A., Cole C. A., Sams R. (2009) Effect of detomidine on visceral and somatic nociception and duodenal motility in conscious adult horses. Vet. Anaesth. Analg. 36, 162-172

Freeman S. L., England G. C. (2000) Investigation of romifidine and detomidine for the clinical sedation of horses. Vet. Rec. 147, 507-51 1

Gasser H., Erlanger J. (1927) The role played by the sizes of the constituent fibers of a nerve trunk in determining the form of its action potential wave. Am. J. Physiol. 80, 522-547

Gozalo-Marcilla M., Gasthuys F., Schauvliege S. (2015) Partial intravenous anaesthesia in the horse: a review of intravenous agents used to supplement equine inhalation anaesthesia. Part 2: opioids and alpha-2 adrenoceptor agonists. Vet. Anaesth. Analg. 42, 1-16

Gozalo-Marcilla M., Gasthuys F., Schauvliege S. (2014) Partial intravenous anaesthesia in the horse: a review of intravenous agents used to supplement equine inhalation anaesthesia. Part 1 : lidocaine and ketamine. Vet. Anaesth. Analg. 41, 335-345

Gozalo-Marcilla M., Hopster K., Gasthuys F., Hatz L., Krajewski A. E., Schauvliege S. (2013) Effects of a constant-rate infusion of dexmedetomidine on the minimal alveolar concentration of sevoflurane in ponies. Equine Vet. J. 45, 204-208

Gracely R. H. 1999. Studies of pain in human subjects. Pages 385 407 in Textbook of pain. 4th ed. P. D. Wall and R. Melzack, ed. Churchill Livingstone, London

Guirimand F., Chauvin M., Willer J. C., Le Bars D. (1995) Effects of intravenous morphine and buprenorphine on a $C$-fiber reflex in the rat. J. Pharmacol. Exp. Ther. 273, 830-841 
Hamm D., Turchi P., Jochle W. (1995) Sedative and analgesic effects of detomidine and romifidine in horses. Vet. Rec. 136, 324-327

Jinks S. L., Martin J. T., Carstens E., Jung S. W., Antognini J. F. (2003) Peri-MAC depression of a nociceptive withdrawal reflex is accompanied by reduced dorsal horn activity with halothane but not isoflurane. Anesthesiology 98, 1128-1138

Jochle W., Hamm D. (1986) Sedation and analgesia with Domosedan (detomidine hydrochloride) in horses: dose response studies on efficacy and its duration. Acta Vet. Scan. 82, 69-84

Jurna I., Heinz G. (1979) Differential effects of morphine and opioid analgesics on $A$ and $C$ fibre-evoked activity in ascending axons of the rat spinal cord. Brain Res. 171, 573-576

Kalpravidh M., Lumb W. V., Wright M., Heath R. B. (1984a) Analgesic effects of butorphanol in horses: dose-response studies. Am. J. Vet. Res. 45, 211-216

Kalpravidh M., Lumb W. V., Wright M., Heath R. B. (1984b) Effects of butorphanol, flunixin, levorphanol, morphine, and xylazine in ponies. Am. J. Vet. Res. 45, 217-223

Kamerling S., Wood T., DeQuick D., Weckman T. J., Tai C., Blake J. W., Tobin T. (1989) Narcotic analgesics, their detection and pain measurement in the horse: a review. Equine Vet. J. 21, 4-12

Kamerling S. G., Cravens W. M., Bagwell C. A. (1988) Objective assessment of detomidine-induced analgesia and sedation in the horse. Eur. J. Pharmacol. 151, 1-8

Kamerling S. G., DeQuick D. J., Weckman T. J., Tobin T. (1985a) Dose-related effects of fentanyl on autonomic and behavioral responses in performance horses. Gen. Pharmacol. 16, 253-258

Kamerling S. G., Weckman T. J., DeQuick D. J., Tobin T. (1985b) A method for studying cutaneous pain perception and analgesia in horses. J. Pharmacol. Methods 13, 267-274

Kohn C. W., Muir W. W. 3rd (1988) Selected aspects of the clinical pharmacology of visceral analgesics and gut motility modifying drugs in the horse. J. Vet. Intern. Med. 2, 85-91

Le Bars D., Gozariu M., Cadden S. W. (2001) Animal models of nociception. Pharmacol. Rev. 53, 597-652

Leandri M., Leandri S., Ghignotti M., Cilli M., Lunardi G. (2011) The ITFR, impulsive tail flick reflex by short duration nociceptive stimuli. Neurosci. Meth. 199, 69-77

Levionnois O. L., Menge M., Thormann W., Mevissen M., Spadavecchia C. (2010) Effect of ketamine on the limb withdrawal reflex evoked by transcutaneous electrical stimulation in ponies anaesthetised with isoflurane. Vet. J. 186, 304-311

Love E. J., Murrell J., Whay H. R. (2011) Thermal and mechanical nociceptive threshold testing in horses: a review. Vet. Anaesth. Analg. 38, 3-14

Love E. J., Pelligand L., Taylor P. M., Murrell J. C., Sear J. W. (2015) Pharmacokinetic-pharmacodynamic modelling of intravenous buprenorphine in conscious horses. Vet. Anaesth. Analg. 42, 17-29

Lundberg A. (1979) Multisensory control of spinal reflex pathways. Prog. Brain Res. 50, 11-28

Mendell L. M., Wall P. D. (1965) Responses of single dorsal cord cells to peripheral cutaneous unmyelinated fibers. Nature 206, 97-99

Merskey H. (1991) The definition of pain. Eur. J. Psychiatry 6, 153-159

Messenger K. M., Davis J. L., LaFevers D. H., Barlow B. M., Posner L. P. (2011) Intravenous and sublingual buprenorphine in horses: pharmacokinetics and influence of sampling site. Vet. Anaesth. Analg. 38, 374-384

Moens Y., Lanz F., Doherr M., Schatzmann U. (2003) A comparison of the antinociceptive effects of xylazine, detomidine and romifidine on experimental pain in horses. Vet. Anaesth. Analg. 183-190

Muir W. W. (2010) NMDA receptor antagonists and pain: ketamine. Vet. Clin. North Am. Equine Pract. 26, 565-578

Nannarone S., Cenani A., Gialletti R., Pepe M. (2015) Clinical comparison of two regimens of lidocaine infusion in horses undergoing laparotomy for colic. Vet. Anaesth. Analg. 42, 150-156

Neziri A. Y., Andersen O. K., Petersen-Felix S., Radanov B., Dickenson A. H., Scaramozzino P., Arendt-Nielsen L., Curatolo M. (2010) The nociceptive withdrawal reflex: normative values of thresholds and reflex receptive fields. Eur. J. Pain 14, 134-141
Peiro J. R., Barnabe P. A., Cadioli F. A., Cunha F. Q., Lima V. M., Mendonca V. H., Santana A. E., Malheiros E. B., Perri S. H., Valadao C. A. (2010) Effects of lidocaine infusion during experimental endotoxemia in horses. J. Vet. Intern. Med. 24, 940-948

Peterbaver C., Larenza P. M., Knobloch M., Theurillat R., Thormann W., Mevissen M., Spadavecchia C. (2008) Effects of a low dose infusion of racemic and S-ketamine on the nociceptive withdrawal reflex in standing ponies. Vet. Anaesth. Analg. 35, 414-423

Petersen-Felix S., Arendt-Nielsen L., Bak P., Fischer M., Bjerring P., Zbinden A. M. (1996) The effects of isoflurane on repeated nociceptive stimuli (central temporal summation). Pain 64, 277-281

Quasha A. L., Eger E. I., 2nd, Tinker J. H. (1980) Determination and applications of MAC. Anesthesiology 53, 315-334

Rezende M. L., Wagner A. E., Mama K. R., Ferreira T. H., Steffey E. P. (2011) Effects of intravenous administration of lidocaine on the minimum alveolar concentration of sevoflurane in horses. Am. J. Vet. Res. 72, 446-451

Risberg A., Spadavecchia C., Ranheim B., Krontveit R., Haga H. A. (2014) Antinociceptive effects of three escalating dexmedetomidine and lignocaine constant rate infusions in conscious horses. Vet. J. 202, 489-497

Robertson S. A., Sanchez L. C. (2010) Treatment of visceral pain in horses. The Veterinary clinics of North America. Equine pract. 26, 603-617

Rohrbach H., Korpivaara T., Schatzmann U., Spadavecchia C. (2009) Comparison of the effects of the alpha-2 agonists detomidine, romifidine and xylazine on nociceptive withdrawal reflex and temporal summation in horses. Vet. Anaesth. Analg. 36, 384-395

Rossi A., Decchi B. (1994) Flexibility of lower limb reflex responses to painful cutaneous stimulation in standing humans: evidence of load-dependent modulation. J. Physiol. 481, 521-532

Schatzmann U., Armbruster S., Stucki F., Busato A., Kohler I. (2001) Analgesic effect of butorphanol and levomethadone in detomidine sedated horses. J. Vet. Med. A Physiol. Pathol. Clin. Med. 48, 337-342

Schovenborg J., Kalliomaki J. (1990) Functional organization of the nociceptive withdrawal reflexes. I. Activation of hindlimb muscles in the rat. Exp. Brain Res. 83, 67-78

Shahani B. (1970) Flexor reflex afferent nerve fibres in man. J. Neurol. Neurosurg. Psychiatry 33, 786-791

Shahani B. T., Young R. R. (1971) Human flexor reflexes. J. Neurol. Neurosurg. Psychiatry 34, 616-627

Sherrington C. S. (1910) Flexion-reflex of the limb, crossed extension-reflex and reflex stepping and standing. J. Physiol. (Lond.) 40, 28-121

Sivilotti L. G., Thompson S. W., Woolf C. J. (1993) Rate of rise of the cumulative depolarization evoked by repetitive stimulation of small-caliber afferents is a predictor of action potential windup in rat spinal neurons in vitro. J. Neurophysiol. 69, 1621-1631

Spadavecchia C., Andersen O. K., Arendt-Nielsen L., Spadavecchia L., Doherr M., Schatzmann U. (2004) Investigation of the facilitation of the nociceptive withdrawal reflex evoked by repeated transcutaneous electrical stimulations as a measure of temporal summation in conscious horses. Am. J. Vet. Res. 65, 901-908

Spadavecchia C., Arendt-Nielsen L., Andersen O. K., Spadavecchia L., Doherr M., Schatzmann U. (2003) Comparison of nociceptive withdrawal reflexes and recruitment curves between the forelimbs and hind limbs in conscious horses. Am. J. Vet. Res. 64, 700-707

Spadavecchia C., Arendt-Nielsen L., Andersen O. K., Spadavecchia L., Schatzmann U. (2005) Effect of romifidine on the nociceptive withdrawal reflex and temporal summation in conscious horses. Am. J. Vet. Res. 66, 1992-1998

Spadavecchia C., Arendt-Nielsen L., Spadavecchia L., Mosing M., Aver U., van den Hoven R. (2007) Effects of butorphanol on the withdrawal reflex using threshold, suprathreshold and repeated subthreshold electrical stimuli in conscious horses. Vet. Anaesth. Analg. 34, 48-58

Spadavecchia C., Levionnois O., Kronen P., Andersen O. K. (2010) The effects of isoflurane minimum alveolar concentration on withdrawal reflex activity evoked by repeated transcutaneous electrical stimulation in ponies. Vet. J. 183, 337-344 
Spadavecchia C., Levionnois O., Kronen P. W., Leandri M., Spadavecchia L., Schatzmann U. (2006) Evaluation of administration of isoflurane at approximately the minimum alveolar concentration on depression of a nociceptive withdrawal reflex evoked by transcutaneous electrical stimulation in ponies. Am. J. Vet. Res. 67, 762-769

Spadavecchia C., Spadavecchia L., Andersen O. K., Arendt-Nielsen L., Leandri M., Schatzmann U. (2002) Quantitative assessment of nociception in horses by use of the nociceptive withdrawal reflex evoked by transcutaneous electrical stimulation. Am. J. Vet. Res. $63,1551-1556$

Strimbu-Gozariu M., Guirimand F., Willer J. C., Le Bars D. (1993) A sensitive test for studying the effects of opioids on a $C$-fibre reflex elicited by a wide range of stimulus intensities in the rat. Eur. J. Pharmacol. 237, 197-205

Taylor P., Coumbe K., Henson F., Scott D., Taylor A. (2014) Evaluation of sedation for standing clinical procedures in horses using detomidine combined with buprenorphine. Vet. Anaesth. Analg. $41,14-24$

Taylor P. M., Hoare H. R., de Vries A., Love E. J., Coumbe K. M., White K. L., Murrell J. C. (2016) A multicentre, prospective, randomised, blinded clinical trial to compare some perioperative effects of buprenorphine or butorphanol premedication before equine elective general anaesthesia and surgery. Equine Vet. J. 48, 442-450

Torfs S., Delesalle C., Dewulf J., Devisscher L., Deprez P. (2009) Risk factors for equine postoperative ileus and effectiveness of prophylactic lidocaine. J. Vet. Intern. Med. 23, 606-61 1

Treede R. D. (2016) Gain control mechanisms in the nociceptive system. Pain 157, $1199-1204$

Willer J. C. (1977) Comparative study of perceived pain and nociceptive flexion reflex in man. Pain 3, 69-80

Willer J. C., Bathien N. (1977) Pharmacological modulations on the nociceptive flexion reflex in man. Pain 3, 111-119

Willer J. C., Bussel B. (1980) Evidence for a direct spinal mechanism in morphine-induced inhibition of nociceptive reflexes in humans. Brain Res. 187, 212-215

Erweiterte Zusammenfassung

\section{Das Modell des Nozizeptiven Rückziehreflexes beim Pferd}

Die Herausforderung, Schmerz beim Pferd effektiv zu behandeln, ist mit der langen Geschichte der Mensch-Pferd-Beziehung verbunden. Effektive als auch sichere schmerzlindernde Strategien sind notwendig um sowohl spontan aufgetretenen als auch perioperativen Schmerz zu lindern. Um die Physiologie der Nozizeption zu untersuchen wird der nozizeptive Rückziehreflex (NWR) als Alternative zu den klassischen thermalen, mechanischen und elektrischen Modellen in der Schmerzforschung des Pferdes vorgeschlagen. Dieses Modell erlaubt durch neurophysiologische Charakterisierung der ausgelösten Reaktion nicht nur eine zuverlässige Definition des nozizeptiven Schwellenwerts, sondern ermöglicht auch das Plotten einer Stimulus-Reaktion-Kurve und die Beurteilung von temporalen Summationsmechanismen. Ziel dieser Veröffentlichung war die Zusammenfassung der Erfahrungen und Ergebnisse erhoben über das NWR-Modell bei Pferden über die letzten 15 Jahre, in erster Linie mit der Intention die physiologischen Charakteristika sowie die Modulation über analgetische und anästhetische Komponenten zu beschreiben. Der nozizeptive Rückziehreflex (NWR) ist ein polysynaptischer spinaler Reflex verantwortlich für die nozifensive Reaktion zum Schutz der Integrität des Körpers gegenüber schädlichen Einwirkungen.
In der Humanmedizin wird der NRW als zuverlässige Methode zu Definition und Quantifizierung von spinalen nozizeptiven Prozessen und als Ergänzung zu psychophysikalischen Methoden für die Schmerzerfassung eingesetzt. Beim Pferd kann der NWR durch elektrische transkutane Stimulation eines peripheren sensorischen Nerven ausgelöst und durch Elektromyographie-Elektroden an den am NWR beteiligten Muskeln erfasst werden. Da nicht-nozizeptive Fasern einen niedrigeren Schwellenschwert bei elektrischen Stimuli aufweisen im Vergleich zu nozizeptive Fasern ist es möglich, zwischen den beiden Gruppen zu unterschieden. Somit sollte die Beurteilung der Qualität des Reizes und der Rekrutierung von nozizeptiven afferenten Neuronen auf den Charakteristika der elektromyographischen Reaktion beruhen vor allen dem Timing der verschiedenen Komponenten. Eine reflexartige Reaktion kann nur dann als wahrer NWR angesehen werden, wenn sie innerhalb eines Zeitabschnitts kompatibel mit der Leitungsgeschwindigkeit von Ad-Fasern auftritt. Des Weiteren muss in diesem Zeitbereich ein klar erkennbarer EMG-Burst assoziiert mit einer konsistenten aversiven Verhaltensreaktion zu beobachten sein, so dass eine Definition eines zuverlässigen Schwellenwertes erfolgen kann. Reaktionen auf Stimulations-Intensitäten niedriger und höher diesem Schwellenwert können zur Erstellung einer Stimulus-Reaktions-Kurve quantifiziert werden. Weiterhin ist es möglich über wiederholte Stimulation mit unterschwelliger Intensität das Phänomen der temporalen Summation auszulösen. Diese stellt mit großer Wahrscheinlichkeit die frühe Phase des Wind up Phänomens dar und ist von besonderem Interesse um zentrale integrative Mechanismen des Schmerzprozess zu beurteilen. Nach Bestimmung der individuellen NWR-Schwellenwerte können wiederholt unterschwellige Stimulation ausgeübt werden um die Schwellenwert-Intensität zur Auslösung der temporalen Summation zu finden.

Unterschiedliche Analgetika und Anaesthetika wurden beim Pferd mit dem NWR- Modell untersucht. a2-Agonisten, welche in der Veterinärmedizin beim Pferd für Sedation und Analgesie weltweit eingesetzt werden, waren die ersten Medikamente bei denen die Modulation des NWR und die temporale Summation beim Pferd erprobt wurden. Unterschiedliche Autoren beschrieben die analgetische Effizienz unter experimentellen Bedingungen bei Verwendung von viszeralen und somatischen Schmerzmodell. In Hinblick auf Romifidin, ein oft eingesetzter $\alpha 2$-Agonist, wurden widersprüchliche Ergebnisse veröffentlicht. Zum Verständnis der anti-nozizeptiven Aktivität dieses Medikaments beim Pferd sollte eine pharmakologischen Studie mit NWR-Modell beitragen. Das vornehmliche Ergebnis war, dass NRW- und temporaler SummationsSchwellenwert nach systemischer Gabe von Romifidin um annährend das dreifache anstieg und dass dies bis zu 55 Minuten nach Verabreichung des Medikaments persistierte und so die anti-nozizeptive Wirkung dieses $\alpha 2$-Agonisten bestätigt wird. Ein weiteres prospektives, verblindetes Crossover-Experiment mit NWR-Modell verglich die anti-nozeptiven Eigenschaften von mit sedativ equipotenter Dosis intravenös verabreichten Xylazin, Romifidin und Detomidin. Während der Grad der Anti-Nozizeption der drei Wirkstoffe vergleichbar war, war die Wirkungsdaver wirkstoffspezifisch und zwar zeigte Romifidin eine längere Wirkdaver als Detomidin und Xylazin. Interessanterweise konnte dies in Hinblick auf die Sedation nicht nachvollzogen werden, die bei Detomidin in Hinblick auf Daver und Ausprägung am größten war. 
Dexmedetomidin, der spezifischste $\alpha 2$-Agonist wird oft in Form einer kontinuierlichen Infusion (CRI) verwendet, entweder um schmerzhafte Prozesse zu behandeln oder um die Menge der Inhalationsanästhetika während einer Vollnarkose zu reduzieren. Wir untersuchten drei ansteigende CRI-Dosierungen $(2,4$, und $6 \mu \mathrm{g} / \mathrm{kg} / \mathrm{h})$ um zu erfassen, welche minimale CRI notwendig ist um eine kontinuierliche Anti-Nozizeption beim wachen Pferd zu gewährleisten. Alle CRls waren in der Lage den Schwellenwert der temporale Summation und der nozizeptiven Toleranz zu erhöhen, doch nur 4 und $6 \mu \mathrm{g} / \mathrm{kg} / \mathrm{h}$ konnte den NWR Schwellenwert kontinuierlich erhöhen.

Das zunehmende Interesse an effizienten Strategien zur Schmerztherapie des Pferdes hat gezeigt, dass Opioide eine wichtige Medikamentengruppe darstellen und dies trotz der Nebenwirkungen, aufgrund derer die Verwendung in den letzten Jahren zurückgedrängt wurde. Bei den Opioiden ist Butorphanol, ein synthetischer Agonist-Antagonist wahrscheinlich die am häufigsten bei Pferden eingesetzte Substanz. Eine einzelne Dosis von $0.1 \mathrm{mg} \cdot \mathrm{kg}^{-1}$ Butorphanol systemisch verabreicht verändert die Schwellenwerte von NWR und der temporale Summation nicht, so dass davon ausgegangen wird dass die ausgelöste A $A$-Faseraktivität nicht inhibiert wird, wie es auch für andere Opioide in der Humanmedizin und bei Labortieren nachgewiesen wurde. Umgekehrt hat Butorphanol nachweisbare Wirkungen auf Parameter, die auf Veränderungen des nozizeptiven Systems und der supraspinale Integration hindeuten. Dies kann, wenn auch von kurzer Dauer, die klinische Evidenz begründen. Buprenorphin stellt als Analgetikum für Pferde eine Alternative zu Butorphanol dar.

Da keine Daten zur Behandlung von Fohlen zur Verfügung stehen, untersuchten wir die anti-nozizeptive Effizienz von Buprenorphin beim Fohlen mit Hilfe des NWR-Modells. Eine Dosis von $10 \mu \mathrm{g} / \mathrm{kg}$ wurde intramuskulär 2 und 11 Tage alten Fohlen verabreicht. Vergleichbar mit Butorphanol war der beste Indikator für die hervorgerufene Anti-Nozizeption beim Einsatz des NWR-Modells signifikante Veränderungen der Stimulus-Reaktions-Kurve.

In den letzten Jahren wurde systemisch verabreichtes Lidocain zur wichtigen Komponente des Anästhesie-Protokolls bei Pferden. Dies insbesondere zur Erzielung einer postoperativen Analgesie nach Laparotomie. Da die anti-nozizeptiven Eigenschaften von Lidocain alleine nicht validiert waren, untersuchten wir bei wachen Pferden drei ansteigende Dosierungen von intravenösen CRls von Lidocain $(20,40$ und $60 \mu \mathrm{g} / \mathrm{kg} / \mathrm{h}$ ) verabreicht nach einem Bolus. Während keine ersichtliche Sedation zu beobachten war, wurde bei der Dosierung $40 \mu \mathrm{g} / \mathrm{kg} / \mathrm{h}$ und höhereine kontinuierliche signifikante AntiNozizeption nachgewiesen. Die CRI von $20 \mu \mathrm{g} / \mathrm{kg} / \mathrm{h}$ war lediglich in der Lage die Toleranz von wiederholten Stimulationen zu steigern, was auch bei dieser niedrigen Dosierung auf einige antihyperalgetische Eigenschaften schließen lässt.

Ketamin ist ein dissoziatives Anästhetikum und beim Pferd das Mittel der Wahl für eine Narkoseinduktion. Trotz der klinischen Evidenz der analgetischen Wirkungen von Ketamin, existiert nur wenig experimentelle Evidenz in Hinblick auf dessen antinozizeptive Aktivität bei Pferden. Wir beurteilten die substanzspezifische anti-nozizeptive Aktivität von racemischem Ketamin und S-Ketamin bei einer "equipotenten" Dosierung in Form einer CRI bei wachen Ponies. Die Ponies erhielten über 1 Stunde entweder $0,6 \mathrm{mg} / \mathrm{kg}$ racemisches Ketamin (group RS) oder $0,3 \mathrm{mg} / \mathrm{kg} \mathrm{S}$-Ketamin (group S) gefolgt von $20 \mu \mathrm{g} / \mathrm{kg} / \mathrm{h}$ racemisches Ketamin (group RS) oder $10 \mu \mathrm{g} / \mathrm{kg} / \mathrm{h} \mathrm{S}$-Ketamin (group S). Erstens beobachteten wir, dass der Ketamin-Bolus gefolgt von der CRI bei stehenden Ponies gut toleriert wurde und zweitens dass racemisches Ketamin in der Lage war den Schwellen- und Supra-Schwellenwert von NWR zu senken, wozu S-Ketamin nicht in der Lage war. Diese impliziert dass die erwartete Equipotenz keine Anti-Nozizeption einschließt. In einer nachfolgenden Studie wurde die Effizienz einer kontrollierten Ketamininfusion auf den NWR und die temporale Summation unter Isofluran-Vollnarkose untersucht. Stimulus-Reaktions-Kurven nach einzelnen und wiederholten elektrischen Stimulationen waren während der Ketamininfusion bei einer Plasmakonzentration von $2 \mu \mathrm{g} / \mathrm{ml}$ abgeflacht und signifikante Veränderungen des NWR und der temporalen Summation wurden festgestellt. Diese Ergebnisse unterstützen die Verwendung eine niedrig-dosierte Ketamin-CRI zur Ermöglichung einer Anti-Nozizeption bei Pferden.

Die Beurteilung der spezies-spezifische ImmobilisierungsFähigkeit von Inhalationsnarkotika erfolgt in der Regel über die minimale alveolare Konzentration (MAC), die ED50 anästhetische Konzentration, die notwendig ist, um ungerichtete und gezielte Bewegungen, ausgelöst durch einen supramaximalen Stimulus, zu verhindern. Neuere Studien zeigten, dass Mechanismen und Wirkungsbereiche der flüchtigen Wirkstoffe, die für die Immobilität verantwortlich sind, eher Regionen im Rückenmark als solche im Gehirn betreffen. Somit steigt das Interesse an einer abgestuften anästhetischen Suppression einfacher spinaler nozizeptiver Reflexe bei AnästhetikumKonzentrationen im Bereich der MAC als eine mögliche quantitative Messung der spinalen Aktion. Unsere IsofluranStudien mit Einzel- als auch wiederholten Stimulations-Paradigma zeigte, dass subtile Veränderungen in der sensomotorischen Verarbeitung durch die NWR-Methode nachgewiesen werden konnten. Leichte Veränderungen der Isofluran-Konzentrationen verursachen Veränderungen der Schwellenwerte von NWR und der temporalen Summation. Eine vollständige Unterdrückung des NWR wurde bei Konzentrationen erzielt, die grobe gezielte Bewegungen verhinderten. Diese Studie zeigte, dass es möglich ist, andere Parameter als die MAC zu verwenden um die immobilisierende Wirksamkeit von Inhalations-Anästhetika bei Pferden zu quantifizieren. In diesem Übersichtsartikel beschrieben wir die Möglichkeiten und Grenzen der Therapie-Ansätze für akuten Schmerz. Unabhängig von vorherigen Studien zur Beurteilung der Effizienz never analgetischer Wirkstoffe kann der NWR als komplementäres diagnostisches Mittel zur klinischen Beurteilung der sensorischen Dysfunktion bei Pferden verwendet werden.

Schlüsselwörter: Nozizeptiver Rückziehreflex, Pferd, Schmerz, Anästhesie, Tierschutz 